\title{
Heat Treatment of Pitch Obtained from Atmospheric Fixed-Bed Coal Gasification
}

\author{
Phiciato $^{1, *}$, Ika Monika1, and Arie Hardian² \\ ${ }^{1}$ Tekmira Research Center for Minerals and Coal, Ministry of Energy and Mineral, Resources of the Republic of Indonesia, \\ Jl. Jenderal Sudirman No. 623, Bandung 40211, Indonesia \\ ${ }^{2}$ Department of Chemistry, Faculty of Sciences and Informatics, Universitas Jenderal Achmad Yani, \\ J. Terusan Jenderal Sudirman, Cimahi 40285, Indonesia
}

Received December 27, 2017; Accepted February 9, 2018

\begin{abstract}
A medium temperature pitch obtained from atmospheric fixed-bed gasifier was distilled at a various time $(1,2$, 3 and $4 \mathrm{~h}$ ) to induce polymerization and the results were compared with a commercial pitch. Aromaticity level of pitches was examined using infrared spectroscopy, elemental analysis and simultaneous thermal analysis (TGDSC). Longer heating time promoted lower moisture content, lower residue yield, higher insoluble fractions, as well as higher ash and carbon content. Although prolonged heat treatments lead to higher aromatization, there was no significant change in aromatization for heat treatment longer than $1 \mathrm{~h}$. The index of aromaticity measured by using elemental analysis was ranged between 0.47 to 1.01, while the result from FTIR spectra showed stagnant value at 0.52. These values were slightly higher than that of pressurized Sasol-Lurgi gasification pitch (0.27).
\end{abstract}

Keywords: coal tar pitch; distillation; coal gasification; aromaticity index; infrared spectroscopy

\section{ABSTRAK}

Pitch suhu medium yang diperoleh dari gasifikasi batubara tipe fixed-bed, didestilasi pada berbagai variasi waktu (1, 2, 3 dan 4 jam) untuk memicu polimerisasi dan kemudian hasilnya dibandingkan dengan pitch ter batubara komersial (CTP). Tingkat aromatisitas pitch dievaluasi dengan menggunakan spektroskopi inframerah, analisis unsur dan analisis termogravimetri simultan (TG-DSC). Semakin lama proses pemanasan maka semakin rendah kandungan air, semakin rendah residu yang didapatkan, semakin tinggi fraksi tidak terlarut, semakin tinggi kadar abu dan kandungan karbon. Walaupun proses perlakuan panas memicu tingkat aromatisasi yang lebih tinggi, namun tidak ada perubahan tingkat aromatisasi yang signifikan untuk proses pemanasan lebih dari 1 jam. Indeks aromatisitas diukur menggunakan analisis unsur dan hasilnya berkisar antara 0,47 sampai 1,01, sedangkan hasil spektrum FTIR menunjukkan nilai tersebut stagnan pada 0,52. Nilai ini sedikit lebih tinggi dari pada CTP hasil gasifikasi Sasol-Lurgi bertekanan tinggi $(0,27)$.

Kata Kunci: coal tar pitch; destilasi; gasifikasi batubara; indeks aromatisasi; spektroskopi inframerah

\section{INTRODUCTION}

Coal tar pitch (CTP) is mainly obtained from the process of coal carbonization and it accounts for 2.5-4.0 mass of the feed coal. The annual production of CTP is related to the amount of coke since coal tar is high value by-product of coke production. Recently, its production is increasing rapidly because of global coke demand [1]. In aluminum industry, CTP is used as a binder pitch for the production of anodes and most of its production is concentrated in China which cause high intercontinental and inland transportation cost [2]. The global needs of anode grade CTP account for about 2.2 million tons/year [3]. This number is still increasing in the next few years especially in a fast-growing country such as Indonesia, where the government plans to create industrial smelter cluster to support national metal industries. Nowadays,

* Corresponding author.

Email address : phiciato@esdm.go.id most of CTP used in aluminum production in Indonesia is imported from somewhere else meanwhile Indonesia is one of the largest exporter of coal in the world [4]. This gap is mainly caused by the lack of coking coal resource which later provokes the absence of coke making industry in Indonesia. Therefore it is important to seek an alternative solution to produce anode grade CTP from another process such as coal gasification.

Commercial CTP generally refers to pyrolysis product of cooking process at high temperature (1000$1100{ }^{\circ} \mathrm{C}$ ) while gasification pitch is generated in gasification process at medium temperature $\left(400-700^{\circ} \mathrm{C}\right)$. The previous study showed that there are several attempts to produce anode grade CTP from coal gasification pitch [5-9]. However, the lack of understanding of pitch composition and heterogeneous

Phiciato et al. 
composition of the raw pitch, make there is no single rule of thumb for all pitches production.

Mokoena et al. showed that gasification pitch alone could not be a substitute for the more aromatic hightemperature pitch because more intense heat treatment will only lead it to coke formation [6]. However, blending with a good understanding of the development of the pitches might provide a good binder pitch material. In typical fixed-bed gasification such as in Sasol-Lurgi process, coal as primary feedstock is gasified at a typical pressure of 30 bar [10]. Nevertheless, the characteristic of pyrolysis products strongly depends on coal petrography composition, gaseous atmosphere [11], temperature and pressure [12]. Coal characteristic and operational condition of the gasifier in Indonesia may be different from that of Sasol-Lurgi in South Africa in which pure oxygen is injected into the pressurized gasifier. The carbon yield of pyrolysis product under pressure condition is $22 \%$ lower, and the insoluble fractions are $55 \%$ higher than that of atmospheric condition because of the high content of functional groups that leads to high reactivity [12]. Meanwhile, the majority of the fixed-bed gasifier in Indonesia operates at atmospheric pressure and uses air instead of pure oxygen as a reactant. This implies different pyrolysis condition which results in different raw tar properties.

In the present work, a raw tar obtained from atmospheric fixed-bed gasification was heat treated in distillation unit and was characterized as a function of heating time. The aim of this study is to seek the optimum heat treatment parameters to produce gasification pitch having properties close to that of commercial pitch or CTP.

\section{EXPERIMENTAL SECTION}

\section{Materials}

The raw material for the production of gasification pitch was coal tar that was collected from pilot plant coal gasifier with feedstock capacity up to $500 \mathrm{~kg} / \mathrm{h}$. The reactor is basically an updraft fixed-bed type coal gasifier in which the air comes at the bottom, and the supply is fed into the chamber concurrently with the movement of product gas. Coal feedstock was a sub-bituminous type having a calorific value of $5600 \mathrm{kcal} / \mathrm{kg}$ (arb) and main characteristic as detailed in Table 1. Tars and volatiles produced in coal gasification were then collected by 55$65 \mathrm{kV}$ wet electrostatic precipitator. Since water and hydrophobic part of tars naturally repulsed each other, excessive water content in tar samples could be simply separated. Tar samples were then heat treated by using distillation process. The residue at the bottom of distillation tube was called as gasification pitch. Gasification pitch was studied and compared to commercial pitch supplied by Himadari Chemical and Industries Limited, India.

\section{Instrumentation}

Elemental analysis of all samples was carried out by Tekmira Research Center for Coal and Minerals using Elemental Analyzer (LECO CHN628 series). The softening point was determined by Simultaneous Thermal Analysis (TGA-DSC) with maximum temperature at $700^{\circ} \mathrm{C}$. FTIR spectra were recorded on a Shimadzu IRAFFINITY-1 spectrometer using $\mathrm{KBr}$ pellet, with the wavenumber ranging from 400 to $4000 \mathrm{~cm}^{-1}$.

\section{Procedure}

\section{Heat treatment}

The term heat treatment refers to the controlled heating temperature at given duration to obtain the desired pitch characteristic by controlling polymerization. Meanwhile, the distillation process refers only to the separation of a mixture by controlling evaporation and condensation of each component. Heat treatment was carried out in distillation steel tube under nitrogen gas flow $(2 \mathrm{~mL} / \mathrm{min})$ to prevent oxidation. Distillation tube is connected to the condenser as illustrated in Fig. 1. Based on the result of thermogravimetric (TG) analysis (Fig. 2), the optimum temperature for eliminating moisture and light components of tar was ranged between $430-450{ }^{\circ} \mathrm{C}$. Thus target temperature was set at $450{ }^{\circ} \mathrm{C}$. The duration of heat treatment was varied between 1 to $4 \mathrm{~h}$.

\section{Solvent fractionation}

The infusible matter was characterized by solvent fractionation of the pitch insoluble in quinoline and

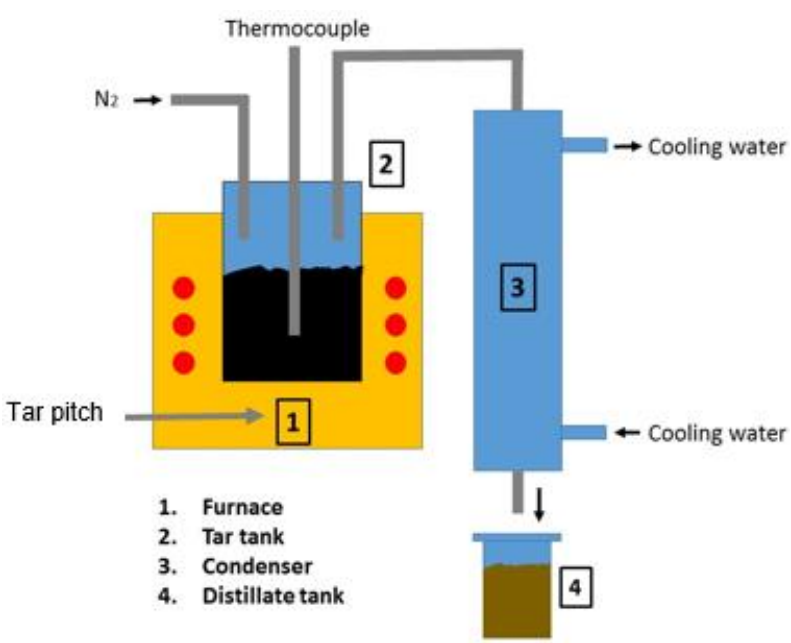

Fig 1. Schematic illustration of distillation process 


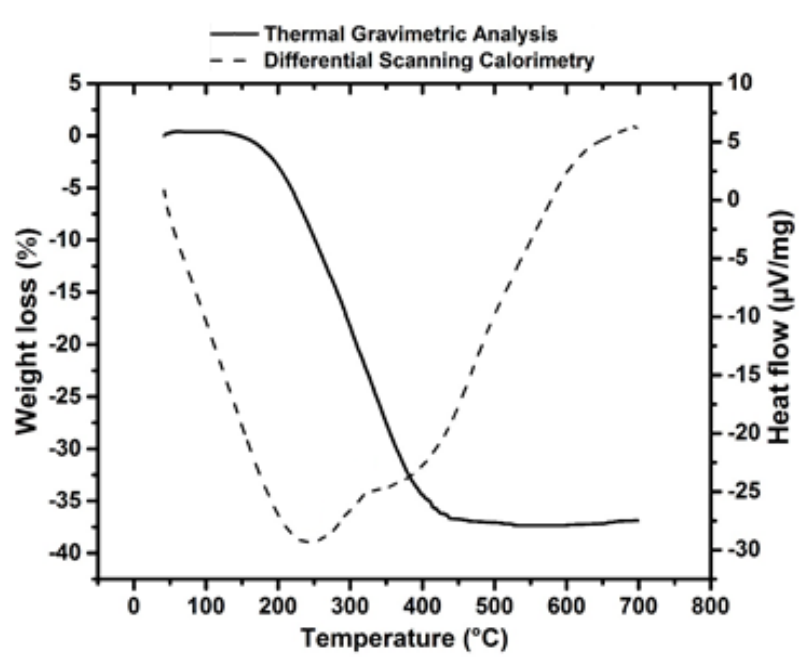

Fig 2. TG and DSC profile of raw tar

toluene. All heat treated samples were crushed and sieved using a 60-mesh sieve. For quinoline insoluble (QI) measurement, samples were dissolved in quinoline (reagent grade Sigma Aldrich) with solvent/solute ratio 2:1 (usually $2.5 \mathrm{~g}$ in $5 \mathrm{~mL}$ of quinoline). Samples were heated at $70^{\circ} \mathrm{C}$ while being stirred using magnetic stirrer for 1 hour. QI was obtained by pouring solution onto filtration paper (Whatman grade 42) and was dried at room temperature for $24 \mathrm{~h}$. Toluene insoluble ( $\mathrm{TI}$ ) was measured by dissolving samples in toluene (reagent grade Sigma Aldrich) with solvent/solute ratio 20:1 (usually $3 \mathrm{~g}$ in $60 \mathrm{~mL}$ of toluene). Samples were stirred at $100{ }^{\circ} \mathrm{C}$ for $1 \mathrm{~h}$ before poured onto filtration paper. Both filtration processes usually take excessive time and in some special cases, it is very difficult. Therefore, to accelerate drying process, the samples should be dried in an oven at $105^{\circ} \mathrm{C}$ for $6-8 \mathrm{~h}$ until they were completely dried. Proximate analysis was then performed by using ASTM D.3172-D3175 while ultimate analysis followed ASTM D.5373.

\section{RESULT AND DISCUSSION}

The results of TG and Differential Scanning Calorimetry (DSC) are used to determine the optimum temperature for distillation. As presented in Fig. 2, the investigated raw tar started losing weight at temperatures above $140{ }^{\circ} \mathrm{C}$ and lost around $37.4 \mathrm{wt} \%$ during its carbonization at temperatures up to $700{ }^{\circ} \mathrm{C}$. Softening point can be calculated by plotting the middle of the incline. The softening point is $143^{\circ} \mathrm{C}$ that occurs when the weight loss is $27 \mathrm{wt} \%$.

The result shows that sample weight decreases slowly when the temperature increases. It decreases linearly with the increase of heat flow indicating that weight loss is mainly due to volatilization of low molecular weight fraction. The first peak appears at

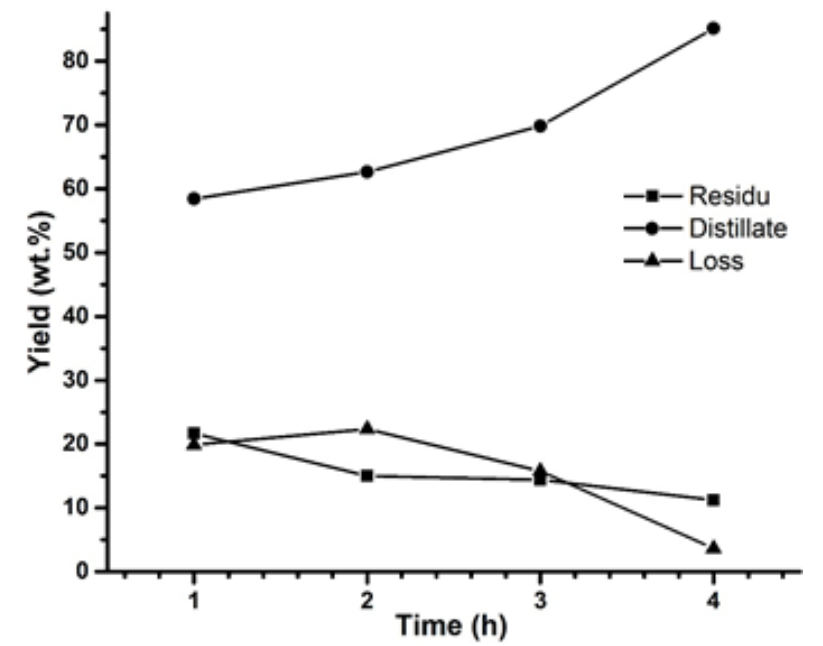

Fig 3. Distillation yield of raw tar

$245{ }^{\circ} \mathrm{C}$, and the weight loss is $8 \mathrm{wt} \%$. The first peak can be attributed to the distillation of the volatile compounds that are stable at their boiling point [13], while the second peak at $345^{\circ} \mathrm{C}$ indicates the removal of light compounds and gases due to cracking and polymerization reactions. In addition, it was observed that during distillation the temperature increased dramatically from room temperature to $200{ }^{\circ} \mathrm{C}$ $\left(7{ }^{\circ} \mathrm{C} / \mathrm{min}\right)$ and then it slowed down at $245{ }^{\circ} \mathrm{C}$ $\left(1.83{ }^{\circ} \mathrm{C} / \mathrm{min}\right)$ and $345{ }^{\circ} \mathrm{C}\left(1.22{ }^{\circ} \mathrm{C} / \mathrm{min}\right)$. This fluctuation of heat rates is in good accordance with the appearance of both peaks in DSC curve. It shows that DSC curve measurement can be useful to determine the appropriate process design for scaling up.

Distillation of pitch at elevated temperature is used to improve the quality of pitch such as softening point, QI and TI content, index of aromaticity, $\mathrm{C} / \mathrm{H}$ ratio, and carbon content. As shown in Fig. 2 the optimum weight loss occurs at $435-450{ }^{\circ} \mathrm{C}$, therefore the distillation process was set to $450{ }^{\circ} \mathrm{C}$, and the result of distillation yield is shown in Fig. 3. The amount of volatile fractions (distillate above $435{ }^{\circ} \mathrm{C}$ ) increases with an increasing in distillation time. The percentage of distillate is in a range of $58-85 \mathrm{wt} \%$ and the average value of residue is $15.57 \mathrm{wt} \%$. On the other hand, loss material indicates the weight loss of material or gaseous that cannot be captured in the condenser. These substances are probably generated due to cracking and polymerization reactions. It increases slightly at $2 \mathrm{~h}$ and decreases afterward. It can be seen that longer heating time does necessarily reduce the loss.

Table 1 shows the result of proximate and elemental analysis of commercial pitch, raw tar, and heat-treated gasification pitch. Moisture content decreases with the increase of heating time. The lowest moisture content and the highest fixed carbon 
Table 1. Proximate and elemental analysis of commercial pitch, raw tar and heat treated pitch

\begin{tabular}{|c|c|c|c|c|c|c|c|}
\hline $\begin{array}{l}\text { Analysis Parameters } \\
\text { (wt\%) }\end{array}$ & Coal & $\begin{array}{c}\text { Raw tar } \\
\text { (gasification) }\end{array}$ & \multicolumn{4}{|c|}{ Heat treated pitch (gasification) } & $\begin{array}{l}\text { Commercial pitch } \\
\text { (coke-oven) }\end{array}$ \\
\hline Proximate(adb) & & & $1 \mathrm{~h}$ & $2 \mathrm{~h}$ & $3 \mathrm{~h}$ & $4 \mathrm{~h}$ & \\
\hline Moisture in air dried & 21.36 & 12.96 & 0.61 & 0.25 & 0.17 & 0.08 & 0.25 \\
\hline Ash & 3.05 & 0.01 & 0.60 & 2.02 & 1.23 & 2.80 & 0.19 \\
\hline Volatile matter & 38.6 & 87.03 & 68.29 & 18.91 & 15.87 & 12.06 & 55.04 \\
\hline Fixed carbon & 41.16 & - & 30.47 & 78.81 & 82.71 & 85.05 & 44.52 \\
\hline \multicolumn{8}{|l|}{ Ultimate } \\
\hline Carbon & 59.62 & 72.97 & 87.55 & 90.00 & 90.23 & 88.86 & 93.42 \\
\hline Hydrogen & 6.18 & 8.78 & 8.04 & 4.14 & 3.50 & 3.53 & 4.33 \\
\hline Nitrogen & 0.87 & 0.27 & 0.72 & 1.01 & 1.07 & 1.11 & 1.23 \\
\hline
\end{tabular}

content are obtained after heat treatment for $4 \mathrm{~h}$. However, the proportion of ash content also increases from $0.01 \mathrm{wt} \%$ to $2.80 \mathrm{wt} \%$, due to the volatilization of light compounds. The obtained data show that longer heating time does not necessarily result in high-quality pitch since the increase of fixed carbon is always followed by the increase ash content. Despite the detrimental effect of heat treatment to ash proportion, all heat treated pitches show moisture content less than $1 \%$. Since $1 \mathrm{~h}$ pitch contains the lowest ash content, it indicates that $1 \mathrm{~h}$ is probably the optimum heating time to meet the standard quality of the commercial pitch.

Fig. 4 contains the FTIR spectra for the four heattreated pitches and for comparison, the obtained commercial pitch. The spectra are very similar to the heat-treated pitches. Meanwhile, there are clear differences between 3100 and $2900 \mathrm{~cm}^{-1}$ with that of the commercial pitch. The peaks near $3100 \mathrm{~cm}^{-1}$ of four heat treated samples are attributed to the aromatic hydrogen (C-H) stretching vibration $[7,14]$ whereas the region near $700-900 \mathrm{~cm}^{-1}$ is attributed to the various bands related to the aromatic, out-of-plane, and $\mathrm{C}-\mathrm{H}$ bending [7]. According to the literature [15], the peaks between 2700 and $2980 \mathrm{~cm}^{-1}$ and $1480-1370 \mathrm{~cm}^{-1}$ of heat treated samples are owing to the aliphatic hydrogen stretching absorption of $-\mathrm{CH}_{2}$ - and $-\mathrm{CH}_{3}$ - structures. All baselines of spectra are corrected before performing plot and rescaled as appeared in Fig. 4. The peaks of $2900 \mathrm{~cm}^{-1}$ of $1 \mathrm{~h}$ are relatively stronger than the rest of heat-treated pitches while it completely disappears in commercial pitch. Both of the peaks at 3100 and $2900 \mathrm{~cm}^{-1}$ are important to discuss since it indicates the aromaticity level of samples.

Aromaticity level or aromaticity indices are an important parameter to measure the material quality of binder in anode for aluminum and steel industries. Aromaticity indices ( $\mathrm{lar}$ ) were calculated from the FTIR spectra following a formula described as appeared on Eq. (1) [14].

$\mathrm{I}_{\mathrm{Ar}}=\frac{\mathrm{A}_{3050}}{\mathrm{~A}_{3050}-\mathrm{A}_{2920}}$

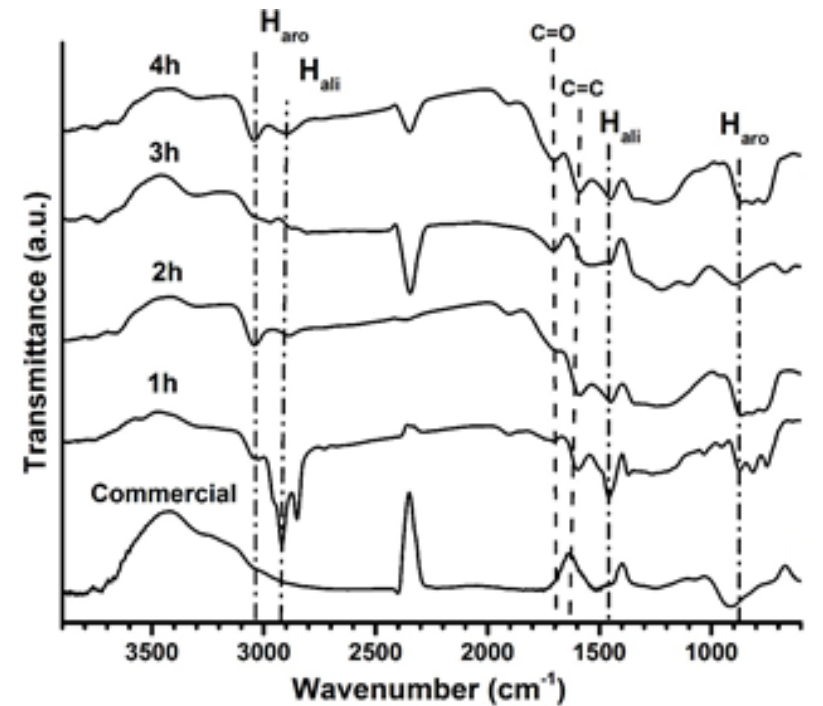

Fig 4. FTIR spectra of commercial and heat-treated gasification pitches $(1,2,3$, and $4 \mathrm{~h})$

where $A_{1 b S} 3050$ and Abs2920 represent the absorption of aromatic and aliphatic stretching vibrations of $\mathrm{C}-\mathrm{H}$ respectively. All spectra baselines are corrected between 3400 and $2000 \mathrm{~cm}^{-1}$ for quantitative analysis. The aromaticity of all pitches is basically at a range of $0.4-0.6$. The ratio of $\mathrm{H}_{\text {aro }} / \mathrm{H}_{\text {ali }}$ shows an increasing trend of aromaticity index with the increase of heating time, as shown in Table 2. In general, $\mathrm{H} / \mathrm{C}$ ratios of insoluble fractions of heat treated pitches are lower than that of commercial pitches. For heat treated pitches, $4 \mathrm{~h}$ has the lowest value indicating its high aromaticity. In contrast, $1 \mathrm{~h}$ pitch is found as the least aromatic pitch.

Compared to FTIR spectra in Fig. 4, the ratio of $\mathrm{H} / \mathrm{C}$ and $\mathrm{I}_{\mathrm{ar}}$ in Table 2 do confirm each other about the effect of longer heating time to aromatization. There is a dramatic change in the ratio of $\mathrm{H}_{\text {aro }}$ and $\mathrm{H}_{\text {ali }}$ at 3100 and $2900 \mathrm{~cm}^{-1}$ respectively between 1 and $4 \mathrm{~h}$ pitches, suggesting that the aromatization has occurred. In contrast, the related peaks are difficult to detect in commercial pitch sample, which make it difficult to 
Table 2. Characteristic of aromaticity of coke-oven pitch, gasification pitch and insoluble fractions

\begin{tabular}{|c|c|c|c|c|c|c|c|c|c|c|c|c|}
\hline \multirow[t]{2}{*}{ Pitch } & \multicolumn{2}{|c|}{$\begin{array}{c}\text { Insoluble } \\
\text { fractions yield } \\
\text { (wt\%) }\end{array}$} & \multicolumn{2}{|c|}{ Carbon (wt\%) } & \multicolumn{2}{|c|}{ Hydrogen (wt\%) } & \multicolumn{2}{|c|}{ Nitrogen (wt\%) } & \multicolumn{3}{|c|}{$\mathrm{H} / \mathrm{C}$} & lar \\
\hline & $\mathrm{TI}$ & $\mathrm{QI}$ & $\mathrm{TI}$ & QI & $\mathrm{TI}$ & QI & $\mathrm{TI}$ & QI & Pitch & QI & $\mathrm{TI}$ & FTIR \\
\hline Commercial & 37.00 & 10.30 & 94.43 & 80.23 & 3.35 & 2.16 & 1.42 & 0.08 & 0.55 & 0.32 & 0.42 & - \\
\hline $1 \mathrm{~h}$ & 58.32 & 30.33 & 86.88 & 84.99 & 5.32 & 6.28 & 1.33 & 1.20 & 1.01 & 0.88 & 0.73 & 0.49 \\
\hline$\pm \stackrel{D}{ \pm} 2 \mathrm{~h}$ & 90.23 & 88.42 & 91.58 & 90.83 & 3.52 & 3.69 & 1.18 & 2.17 & 0.55 & 0.48 & 0.46 & 0.50 \\
\hline 표 $3 \mathrm{~h}$ & 97.18 & 98.23 & 85.74 & 92.01 & 3.31 & 3.45 & 1.16 & 1.99 & 0.46 & 0.45 & 0.46 & 0.49 \\
\hline $4 \mathrm{~h}$ & 98.37 & 99.57 & 86.49 & 90.16 & 3.35 & 3.52 & 1.42 & 2.11 & 0.47 & 0.46 & 0.46 & 0.58 \\
\hline
\end{tabular}

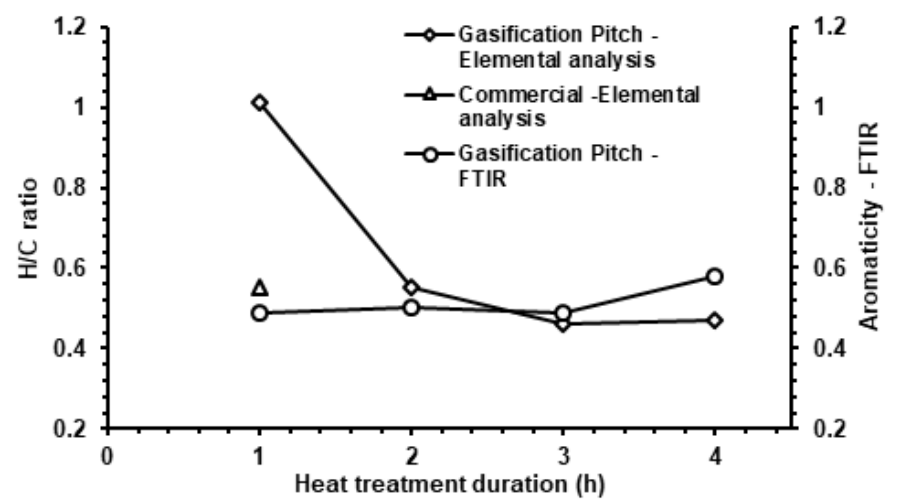

Fig 5. The relation between $\mathrm{H} / \mathrm{C}$ ratio and heat treatment duration showing no significant effect to aromaticity

calculate $\mathrm{I}_{\mathrm{ar}}$ of the commercial pitch. However, the ratio of $\mathrm{H} / \mathrm{C}$ of commercial pitch in Table 2 shows that the pitch is aromatized as well as heat treated pitches with a value of 0.55 . The possible reason for this anomaly is the interference of amide stretch which results in broadening band at those wavelengths.

The similar trends of aromatizationare also observed for both of insoluble fractions, QI and TI. Therefore it can be concluded that longer heating time promotes higher aromatization.This is because prolonged heat-treatment assists Polycyclic Aromatic Hydrocarbon (PAH) groups to form cross-link between molecules, resulting in larger molecules. The reaction routes proposed in the literature [6] suggest that both of cross-link and condensation reactions may take part during heat treatment. However, in this case, the crosslink reaction should be the dominant reactions. It is because pitches from gasification contain high functionalities and more small PAH groups than that of commercial pitch obtained from high-temperature pyrolysis. The longer pitches are heat treated; the higher polymerization may occur and lead to higher insoluble fractions as appeared in Table 2. Nevertheless, it should be noted that heating time longer than $1 \mathrm{~h}$ does not result to a significant change of $\mathrm{H} / \mathrm{C}$ ratio nor lar value, suggesting that $1 \mathrm{~h}$ or less is probably the most optimum parameter. These results are consistent with Mokoena et al. which have shown that prolonged heat treatment of gasification pitch only leads to coke formation [6]. Compared to Mokoena et al. result, the aromaticity index in this study is slightly higher than that of pressurized Sasol-Lurgi pitch having an average value of 0.27 . However, the effect of pressurized atmosphere to pitch characteristics will not be discussed here since it needs further in-depth study.

Both $\mathrm{H} / \mathrm{C}$ ratio and $\mathrm{lar}$ are commonly used to characterize the aromaticity of compound. Fig. 5 shows that the effect of heat treatment duration is not significant to the index of aromaticity obtained from FTIR spectra, although the $\mathrm{H} / \mathrm{C}$ ratio is showing the opposite. The error in $\mathrm{H} / \mathrm{C}$ ratio calculation may come from the insensitivity detector in elemental analyzer since the standard and the instrument used was not dedicated for pitch characterization. However, it is worth mentioning that the lar obtained in this study is stagnant at 0.52 suggesting that $\mathrm{lar}$ of the pitch from atmospheric gasification is higher than that of pressurized gasification (0.27) and closer to that of the commercial pitch.

\section{CONCLUSION}

Although prolonged heat treatments result in higher aromatization, higher insoluble fractions, and higher carbon content. There is no significant change in aromatization for heat treatment longer than $1 \mathrm{~h}$ which lead to conclusion that $1 \mathrm{~h}$ heat treatment is the most optimum parameter. It is possible to produce similar commercial pitch from atmospheric gasification pitch. The success of commercial pitch production from coal gasification pitch will bring beneficial impacts to aluminum smelter industry especially in a country where the resource of coking coal is very limited.

\section{ACKNOWLEDGEMENT}

The authors gratefully acknowledge the support from the Head of R \& D Center for Mineral and Coal Technology and the Head of Department of Chemistry, Faculty of Sciences and Informatics, Universitas Jenderal Achmad Yani for their support and assistance in carrying out this study. The authors also would like to acknowledge all technicians and engineers of the Coal Tar Pitch team. 


\section{REFERENCES}

[1] Li, C., and Suzuki, K., 2010, Resources, properties and utilization of tar, Resour. Conserv. Recycl., 54 (11), 905-915.

[2] Baron, J.T.,, McKinney, S.A.,, and Wombles, R.H.,, 2016, "Coal Tar Pitch-Past, Present and Future" in Essential Readings in Light Metals, Eds. Tomsett, A., and Johnson J., Springer International Publishing, Cham, 177-181.

[3] Perruchoud, R.C., Meier, M.W., and Fischer, W., 2016, "Worldwide Pitch Quality for Prebaked Anodes" in Essential Readings in Light Metals, Eds. Tomsett, A., and Johnson J., Springer International Publishing, Cham, 167-176.

[4] Ikhwan, A., 2015, Market Brief Peluang Ekspor dan Senyawa Hidrokarbon, Taipei Economic and Trade Office, Jakarta.

[5] García, R., Crespo, J.L., Martin, S.C., Snape, C.E., and Moinelo, S.R., 2003, Development of mesophase from a low-temperature coal tar pitch, Energy Fuels, 17 (2), 291-301.

[6] Mokoena, K., Van der Walt, T.J., Morgan, T.J., Herod, A.A., and Kandiyoti, R., 2008, Heat treatment of medium-temperature Sasol-Lurgi gasifier coal-tar pitch for polymerizing to higher value products, Fuel, 87 (6), 751-760.

[7] Wang, X., Shen, J., Niu, Y., Sheng, Q., Liu, G., and Wang, Y., 2016, Solvent extracting coal gasification tar residue and the extracts characterization, $J$ Cleaner Prod., 133, 965-970.

[8] Pan, N., Cui, D., Li, R., Shi, Q., Chung, K.H., Long, H., Li, Y., Zhang, Y., Zhao, S., and Xu, C., 2012, Characterization of middle-temperature gasification coal tar. Part 1: Bulk properties and molecular compositions of distillates and basic fractions, Energy Fuels, 26 (9), 5719-5728.

[9] Suriyapraphadilok, U., Jennis-McGroarty, C., Zel, A., and Andresen, J.M., 2004, The use of gasification pitch and coal tar pitch in carbon anodes, Prepr. Pap. - Am. Chem. Soc., Div. Fuel Chem., 49 (1), 455-456.

[10] van Dyk, J.C., Keyser, M.J., and Coertzen, M., 2006, Syngas production from South African coal sources using Sasol-Lurgi gasifiers, Int. J. Coal Geol., 65 (3-4), 243-253.

[11] Wang, P., Jin, L., Liu, J., Zhu, S., and Hu, H., 2013, Analysis of coal tar derived from pyrolysis at different atmospheres, Fuel, 104, 14-21.

[12] Sima, L., Blanco, C., Santamaría, R., Granda, M., Slaghuis, H., and Menéndez, R., 2003, Relationship between chemical composition and pyrolysis behaviour of a medium temperature pitch (or Lurgi-gasifier pitch), Fuel Process. Technol., 84 (1-3), 63-77.

[13] Pérez, M., Granda, M., Santamaría, R., Morgan, T., and Menéndez, R., 2004, A thermoanalytical study of the co-pyrolysis of coal-tar pitch and petroleum pitch, Fuel, 83 (9), 1257-1265.

[14] Guillen, M.D., Iglesias, M.J., Dominguez, A., and Blanc, C.G., 1992, Semiquantitative FTIR analysis of a coal tar pitch and its extracts and residues in several organic solvents, Energy Fuels, 6 (4), 518-525.

[15] Alcañiz-Monge, J., Cazorla-Amorós, D., and Linares-Solano, A., 2001, Characterisation of coal tar pitches by thermal analysis, infrared spectroscopy and solvent fractionation, Fuel, 80 (1), 41-48. 